\title{
On the organisation of sustainable prerequisites for the subjective well-being and growth of individuals
}

\author{
Sören Augustinsson*, Ulf Ericsson and Pär Pettersson \\ Kristianstad University, School of Health and Society, Kristianstad, Sweden
}

\begin{abstract}
The effects that work has on individuals are not unknown. The importance of work in terms of the subjective well-being and growth of individuals through their work, however, is not as extensively discussed and documented. Risk factors and unhealthy factors have long been discussed at the expense of positive conditions for well-being and personal growth. We like to call work with that type of potential regenerative work. Hence, that is the type of work that we have chosen to focus on in this study. The following research objectives have guided us through the study: Which everyday work processes may contribute to sustainable prerequisites for the subjective well-being and growth of individuals? The study takes an explorative approach to two workplaces - a care unit at a hospital and a manufacturing company. Our aim is to increase the understanding of prerequisites for the well-being and growth of individuals through their work. Three themes emerged in this type of regenerative work: performance, general overview and participation, and dialogue. These themes are problemised by looking at their potential in relation to the organisation of the work. Prerequisites for performance, general overview and participation, and finally dialogue prove to be more efficient in contexts where the complexity of the work and organisation is acknowledged and where there is room for inter-subjective sense-making and self-organising.
\end{abstract}

Keywords: Regenerative work; complexity; performance; general overview and participation; dialogue

Sustainable work systems and the the work and its cognitive, emotional, growth of individuals through their work and physical consequences. When this and organisation, that is, what we call interplay contributes to subjective wellregenerative work (Ericsson, 2010; Kira, being and psychological development, 2003; Kira \& Forslin, 2008; Palm, we refer to this as regenerative work. 2008), constitute the main focus of this How is sustainable work designed and article. Regenerative work focuses on the how may we understand its organisainteraction between the individual and tion? This question is connected to the

${ }^{\star}$ Correspondence to: Sören Augustinsson, Kristianstad University, School of Health and Society, 29188 Kristianstad, Sweden. Email: soren.augustinsson@hkr.se 


\section{S. Augustinsson et al.}

importance of salaries in terms of the well-being and growth of individuals, a slightly underrated aspect that is important to pay more attention to. The psychosocial, as well as the physical, work environment has long been approached in terms of minimising risk. Certainly this is an important approach in all research that deals with workrelated health. We, however, wish to expand on this question. Hence, we have taken a step forward in terms of understanding the contributing factors to the growth and subjective well-being of individuals through their work and organisation.

The effects that every day work processes - including communication and how the work is managed and controlled in the organisation - have on individuals are not unknown. Throughout the 20th century, this question has been widely discussed in labour science and organisational research (Furåker, 1991; Hackman \& Oldham, 1975; Hansen \& Orban, 2002; Lennerlöf, 1999; Pettersson, 1994; Theorell, 2003; Von Otter, 2003). Within this field of research, the traditional view on work and how it is connected to the health and well-being of people has been to look at work as a risk factor. Consequently, questions have revolved around how to best minimise risks and unhealthy factors at work (Johansson \& Johansson, 2004). Heavy lifting and toxic chemicals are examples of such risks (Holmqvist, 2006). Deaths, injuries caused by crushing, falls, and falling objects within the building industry are also examples of important research on preventive unhealthy factors and risk factors (Eriksson, 1991, p. 153). The psychosocial work environment has also been in focus for a long time and has also been approached with the same set of "risk looking glass," an example of this being stress-related research within the field of psychology (Aldwin, 1994; Kahn, 1981; Monat \& Lazarus, 1991).

However, there are theoretical contributions to work that focus on the positive aspects. Many say that work may be of great importance and have positive implications on our social lives and the formation of our identity (see Jahoda, 1979; Kahn, 1981; Kunnen, Bosma, Van Halen, \& Van der Meulen, 2001; Weick, 1995). Furthermore, work may, at its best, offer positive meaning to the health and well-being of individuals (Ericsson, 2010; Forslin, 2003; Frankenhaeuser, 1995).

We argue that the above-mentioned bases for negative and positive effects on the well-being and growth of individuals are not simply consequences of work in itself, but rather consequences of work and its organisation (Jahoda, 1979; Kahn, 1981; Kunnen et al., 2001).

\section{REGENERATIVE WORK}

Work is an activity that includes interaction between humans and something else, requiring some sort of mental and/ or physical effort. Kira (2003, p. 64) states the following: “... a working individual invest [sic] her mental and/or physical resources and those resources are transformed in the work process to work result." These resources may be spent but also regenerated and seen from a long-term perspective to develop. When the energy and the resources of an individual are spent, one ends up feeling physically and/or mentally drained. 
Authors within the stress medical field, such as Frankenhaeuser (1995); Karasek \& Theorell (1990), and Pettersson (1994), explain that this has to do with the dynamic relationship between the ability of individuals and the external demands required of her. The design of this relationship is a vital indicator of the subjective well-being of the individual (Foldspang et al., 2011). Thus, the interpretations of and demands on the individual and how these are valued in view of one's personal ability and available resources are important. If demands are not manageable, this will only result in negative experiences, that is, (negative) stress. Emotional and cognitive overload, however, are not the only factors that may result in people using up their resources. On the contrary, that is, when an activity is not perceived to be developing or inspiring, the result may also be the same (Braverman, 1974; Gardell, 1976; Kira \& Forslin, 2008).

Traditionally, labour science focuses on problemising such workplaces and work that may drain people's resources (Kira, 2003). Forslin says that this tradition or approach needs to be finalised. Presently, there is a need to complete presupposed notions of work, which may form the basis of something that goes beyond minimising destructive factors or achieving highly motivated occurrences - work as a regenerative process that helps fuel human energy (2003, p. 4445). "Humans are naturally productive and feel a need to perform, create value and improve, make use of their ability and develop ..." (Forslin, 2003, p. 13). Naturally, a reasonable basis for this argument is that work which takes up a large part of people's daily lives, also fills a function for survival and well-being through performance, utilisation of one's ability and development. Hence, work has the potential to contribute to personal as well as professional development (Backström, van Eijnatten, \& Kira, 2002; Brulin \& Ekstedt, 2003; Docherty, Forslin \& Shani, 2002; Forslin, 2003).

Reasoning in terms of regenerative work helps expand our horizon and look beyond a compensational approach to the work environment. Simultaneously, this concept may be useless if we fail to define it in more specific terms. Mari Kira (2003) says that the School of Sociotechnology (STS) and Job Characteristic Model (JCM) have helped us identify various psychological work demands. As a result, we are able to utilise these theories in order to draw conclusions on what the system and the work content should look like. However, Kira claims that there are technical limitations primarily in terms of the experiences of individuals. In order to answer the question of how regenerative work should be experienced, Kira looks to Aaron Antonovsky (1987), who says that regenerative work is perceived as being understandable, manageable, and meaningful (Kira, 2003).

Through a limited focus on the design of the system and experiences of it, there is a risk of being caught up in a thought process where you might end up outside the system, simply looking in at it and changing it in a desirable direction (Stacey, 2001; Weick, 1979). There are limitations if one looks at individuals as being participants and co-constructors of their reality. In these theoretically dual approaches, the individual becomes rather passive, and the setting (and structure) is in focus (Ericsson, 2010). 


\section{S. Augustinsson et al.}

If one is to understand regenerative work, one needs to look at dimensions referring to the organising perspective. Organising, in our opinion, should have a process perspective on organisations and look at their development through inter-subjective activities (see for instance Ericsson, 2010). Hence, everyday work processes are chains of actions and events that form the bases for experiences of one's work.

Therefore, the purpose of this study was to frame the interaction between work and the individual, look at how this interaction is interpreted and acted upon and how it influences the individual's well-being. The study has been directed by the following research question:

Which everyday work processes may contribute to sustainable prerequisites for the subjective well-being and growth of individuals?

\section{METHOD}

\section{Workplaces and participants}

This study is based on interviews conducted at two separate workplaces, one being a private manufacturing company, the other a care unit at a hospital. The manufacturing company is a small business in a small town. The area is characterised by a rather high percentage of unemployment within the manufacturing industry, and the companies here are primarily small. Many of the manufacturing companies in the area are subcontractors to major companies. The hospital is located in the south of Sweden and conducts local health services and specialised care treatment within a few choice fields. The study specifically focused on the care unit at the hospital, which consisted of 230 employees headed by an organisational manager. The unit was subdivided into five different care units, which in turn were headed by a department manager. The care unit employees were exclusively medical nurses and assistant nurses.

\section{Interviews}

At the private manufacturing company with 20 employees, 11 people were interviewed for one to two hours. Out of these 11 people, two represented the company management. The reason for these latter interviews was that we wished to compare the opinions of the managers with those of the staff members, which turned out to be fairly similar in their responses. If we had interviewed only the managerial representatives, we would have risked ending up with idealised versions of reality (Alvesson \& Kärreman, 2011). Conversely, if we had only conducted interviews with employees, this could have resulted in a too negative or positive image. This manufacturing company was part of a study that included 17 companies and 50 employees who had received EU reimbursed competence development funding. Out of these 17 companies, this company was outstanding in its attempt to work in a different manner to change and utilise the skills of its staff members. A first reread of the empirical material suggested that this was a regenerative workplace. The other 16 companies were not even remotely close in terms of how the staff members talked about and looked at their workplace. Our analysis of the empirical material used for this 
article is based on a reread of the material in view of how regenerative work may be designed and organised.

We had focus groups at five care unit departments, comprised of approximately ten people in each group, on ten different occasions. In other words, there were two focus groups in each department. These focus groups were followed up at a feedback meeting hosted at each department later. At the feedback meeting, we got underway with a simple interpretation of the two previous meetings, followed by a dialogue between researchers and participants. Each focus group originated in a change at the department, a newly implemented work model called Patient Focus Care (PFC). Based on the PFC model, we discussed some work-related areas, the work organisation, work environment, communication, learning, health, and well-being.

The choice of these two organisational units is due to the internal development projects executed at the units. The projects were of different orientation, although we have found common factors between the organisations with regard to the objective of this article.

\section{Approach and analysis}

The study takes an explorative approach. Over the course of this study, our aim has been to encourage participants in their accounts. Thus, we have tried to stay as close to practice as possible and take into consideration the reality of the participants rather than focusing on a specific predetermined research objective. We have had a fixed set of frames, a field of interest, although the more specific questions were formulated through the parti- cipants and their experiences from their work situations.

All interviews were recorded. They were then transcribed verbatim. The analysis was inspired by narrative studies (Czarniawska, 2008; Johansson, 2005). We have utilised a fairly structured interpreting/analysis model (Coffey \& Atkinson, 1996; Czarniawska, 1999). A narration is characterised by a few basic elements: Condition - Event/actionComplication - and eventually a Sense moral (Coffey \& Atkinson, 1996; Czarniawska, 1999). Through our analysis, we have attempted to look for various conditions such as: which events or actions have generated these conditions, what complications have arisen, and finally how have the participants chosen to describe and assess them, that is, what was the sense moral. In contrast to a thematic analysis that fragments the empirical material, we have used a narrative approach that generates a strongly inter-meshed picture and thus a different understanding of the empirical material.

These extracted sequences and their entirety were later been put into a theoretical frame of references based on theories on regenerative work, organising, sense-making, and complexity.

\section{FIELD RESULTS}

\section{Local conditions for generic interpretation}

\section{The manufacturing company}

The manufacturing company in our study deals in the metal industry, primarily focusing on manufacturing subcontracted pieces of various components that are used as parts in the finished 


\section{S. Augustinsson et al.}

products, put together by other companies. In the last few years, it has undergone many changes, for instance, change of management, expansion and changes in the work- and leadership organisation. Production emphasis has been moved from subcontracted pieces to more specialised products. The company has approximately 20 employees today, most of whom are men.

A fact that separates this company from others in the region and in this study is that all employees are part of the managerial group at the company. There is a CEO. However, the managerial group discuss things and they make decisions.

\section{The care unit}

All meetings with the employees at the care unit dealt with operational changes. The five departments had recently implemented a new work method, Patient Focused Care (PFC). The changes in work methods meant that the care unit office was to be "closed" and replaced with a reception desk. As a replacement, a number of different patient-oriented care offices were to be established and located out in the hallways closer to the wards, so-called care modules or satellite offices. Furthermore, the previous work division was to change. Rather than having medical nurses (ssk) and assistant nurses (usk) working separately, they would do their work in small teams, in which assistant nurses and medical nurses would work side by side. Hence, the analysis of the transcribed material from the care unit has focused on two different conditions: (1) the situation prior to the change; and (2) the situation after the implementation, and finally which events and actions that helped move employees from condition (1) to condition (2). The comparisons, assessments and experiences expressed by the employees with regard to the two conditions (and the move from one to the other) are central to our understanding of the empiric nature of regenerative work.

\section{FINDINGS}

The result section will focus on three themes that were identified through the empiric material, themes that in one way or another reoccurred throughout the narrations of the informants:

- General overview and participation

- Dialogue

\section{- Performance}

Although the three themes intricately affect one another, we have chosen to initially present them individually. Further on, each theme will be described in view of the manufacturing company and then the care unit. The general overview and participation, dialogue and performance turned out to affect the experiences of health and well-being of the employees. Before we present the content of each theme, we would like to offer a brief summarised view on the manufacturing company and the care unit.

\section{General overview and participation}

\section{The manufacturing company}

At this company, the employees are members of the managerial group, as previously mentioned. Routine matters that are normally dealt with by managers 
are their responsibility, although the employees are keenly aware of the position and orientation of the company. On the floor they feel like they know "everything". In the managerial group, the employees say that they "... find out basically everything that is going on here". This managerial group is special. All employees are included. The employees make decisions alongside the company managers in matters large and small. Naturally there is distribution of power. The relationships, however, are characterised by trust and there is an openly questioning climate available to both parties. It is not a given that the staff members or the managers will be able to have things their way. Participation in the company, similar to that of other companies in the previous study, concerns mostly information and the fact that employees are able to voice their opinions whereas the decision making is always up to the managers. In this company, the mutual decision making and participation in the form of responsibility is important. Decisions will of course have consequences for the operation and design of the work, as well as profits for the managers. A typical statement offered by one of the employees is that "... everyone gets to be heard and everything from buying a new floor mop to investing in a new turret lathe is discussed by everyone."

It is not simply addressed. It is addressed and actual decisions are made. Decisions that are later put into the manager records. Everything is registered in consecutive order. At a later follow-up of the company, the record paragraphs had reached number 673 since the managerial group first started.

\section{The care unit}

The reason for the work model PFC being initially discussed had to do with the problems concerning how much time a medical nurse spent on her patients. Following a time study, it showed that a medical nurse spent $70 \%$ of her time at the care office and $30 \%$ with patients. This was a time distribution that the care unit wanted to change. Medical nurses and assistant nurses both describe a situation prior to the change that was characterised by specialisation and topdown management. They said that the reality they were trying to understand was previously characterised by fragmented images. Dealing with complex patient care includes, for example, assistant nurses and medical nurses understanding and having knowledge about the whole patient and not just small fragmented parts of the whole. Such a general overview requires collaboration that goes beyond set boundaries.

When I was new to working as a medical nurse at the Alpha department, I remember my first round. I asked if we were not to go fetch the assistant nurse. I was quickly told - No, write her a note and put it in the room. This division was also apparent in other situations. If, for instance, a patient needed help in their beds, you rang the bell and an assistant nurse came into the room. When she had come to the room she often said, you go and I will phone one of my colleagues (a different assistant nurse) who will help me. Then, before we changed our way of working, us medical nurses had crammed schedules all day long. We just barely found time to have a quick cup of coffee before we made our rounds. At the same time the assistant 
nurses helped each other in taking care of patients. When it was time for us to make our rounds, the assistant nurses went to have their cup of coffee. We never got to know one another, we barely knew who were working together. The medical nurses worked together and the assistant nurses worked together, but the two professional groups never work side by side. Before we started working according to Patient Care Focus, the work of the medical nurses felt like being a secretary. Today things are easier; we work more in teams and plan the day together. It is easier to make our rounds today, when we know the patients better, and it helps when documenting if we know the patient.

(Medical nurse at the Alpha department)

The medical nurses state that the previously uneven distribution of work and the limited communication between different professional groups resulted in many situations when they actually had no idea of whether the patient was, for instance, able to stand or eat on their own. These were so-called "assistantissues," that is, known to the assistant nurses.

\section{Dialogue}

\section{The manufacturing company}

We return to the phenomenon of the managerial group that is so often referred to by the interviewees. Here the employees voice their opinions, ideas and suggestions for operational changes. We wonder if these opinions are actually addressed and taken into consideration, or if the managers simply listen only to make their own decisions anyway.
Answers suggest that this might be true: "It may differ ..." but in the next sentence an answer may be affirmative and imply that things that are discussed "... are put in the report and discussed and very much discussed, actually, if we reached any decision, that suited both parties it was put into the records."

When asked if they ever feel run over they say: "No, I would not call it that, because we get to say what we think and decisions are often made accordingly, unless it has to do with some major issue, but it actually works fine." Important issues that are discussed or should be discussed are talked about by the staff prior to the meeting, not in the form of a formally structured pre-meeting but informally. It is considered a benefit if many voice the same opinion in questions when meeting with the company managers. Hence, the dialogue is not passive in terms of managers simply offering information to staff members; instead everything is decided in this group. One of the employees says:

... we always spend some time
before the meeting talking amongst
ourselves down here, if there is
something that we wish to discuss
and if everyone in the group wants
something to be taken up to dis-
cussion it is much easier, rather
than having some individual nag-
ging about something upstairs.
This works pretty well.

That there is room for opinions is confirmed by managers and staff members alike. A manufacturing employee says about the meetings that "... everyone is pretty strong-minded too, if there is something that you do not want to do, it may be tough sometimes. But it usually turns out fine eventually." 


\section{The care unit}

The assistant nurses and the medical nurses said that for the above presented theme general overview and participation to become a reality, communication needed to exist. Of course there has always been some kind of communication at the departments, which was strongly emphasised in all groups. The quality of this communication, however, differed. This is just one example from the old world when we were three 28 departments. At one of the departments, the department manager offered a status report each morning, but only medical nurses were present and got to learn about things to come. The door opened when the assistant nurses were allowed to enter... there is talk about hierarchy and changes and you probably think it sounds like the 19th century, but this was not that long ago.

From a medical nurse at the Beta Department:

After the rounds, you found a note in another room, about things that needed to be done. You wondered what century you were in, really? You did not talk, there was only this note... We were also sat at different tables when we took our coffee break (assistant nurses and medical nurses), but this is not true anymore ... you hear about other departments that they do not take their coffee breaks at the same time, that they do not want to share their coffee breaks. (Assistant nurse at the Gamma department)

The employees are constantly trying to emphasise that the preferential right of interpretation of one professional group or the other within a specific field of expertise had evened out after the implementation of PFC. We believe that our informants meant that the integration between assistant nurses and medical nurses resulted in an increase of inter-human meetings and conversations (in relation to work assignments), resulting in meaning that was negotiated through dialogue.

The medical nurses claimed that, by becoming closer to the patients and having more dialogue with the assistant nurses, that they were able to form an opinion and gather knowledge about the patient's temporary condition, abilities, movement. This gave rise to a whole new set of prerequisites when it came to treating the patient as a unique individual. The changes in communication meant that the two professional groups exchanged opinions more often, for example, both assistant nurses and medical nurses, and thus gained a higher level of learning and knowing. Understanding of the general overview increased when dealing with patients. This exchange between professional groups also offered new insights into the assignment and things that needed to be done at the departments. In addition to, or because of, these employees at the different departments expressed a sense of feeling more joy and pleasure - that work simply became more fun.

\section{Performance}

\section{The manufacturing company}

The realisation of the managerial group, according to many of those interviewed, has meant a new sense of responsibility in everyday work situations for the employees. Although many of those 


\section{S. Augustinsson et al.}

interviewed say that they have always taken a huge responsibility for their work, they still say that this responsibility has widened and developed due to the new organisation. Responsibility has become a collective thing and at the same time more independent.

Yes, the greatest thing is the managerial group and that you get to feel responsibility, for how things should be and what you should do. Yes, we have a hell of a lot of responsibility, in my opinion. We have more of that now, and it is more independent, so to speak. (One of the employees)

Employees are individually responsible for planning their work so that it is profitable for their relationship with customers and the product quality standards. One of the workers says that the only thing that annoys him is when unscheduled things occur, but they know how to deal with those. They have room to manoeuvre, say employees:

... I can plan a lot, actually. But we are pretty flexible. Things may always happen that disrupts the schedule, but otherwise we are pretty independent, in my opinion ..." According to the workers, the thing that sets the rules for the planning of their work is consideration of the customers. Incoming orders are what you have to adhere to. Those are the bases of everything, the customers so to speak.

This type of decision making is apparently made on the floor, in the work team. A development engineer at the company has an even less structured workday. This professional group focuses more on the keywords 'flexibility' and 'complexity' than those on the floor.
Flexibility means that they have direct contact with company customers and are often faced with unexpected situations. Complexity means that their work encompasses so many areas both in terms of products and work assignmentsthat their workday becomes "chopped up". The narration of the development engineer in terms of his ability to plan and take individual responsibility is very similar to that of the floor workers when they describe their workday.

Personal and collective responsibility at the company is something that constantly reoccurs in interviews with employees at the company. They say that they feel like "they do not have anyone supervising them." The organising of work at the company seems to be separated from a modern work organisation where the manager makes direct decisions or through a representative is constantly supervising the organisation members below. At this company, employees feel that they are not supervised by the organisation. Not feeling supervised, but as someone who can be trusted, is a good thing, which shows in the room for manoeuvre.

Do you feel that you are given enough space to take responsibility for your work?

Yes, I really do, actually, because no one is there to give you directions all the time. I am often the last person in the production chain, at least in terms of the subcontracting manufacturing before the products reach the customer. So you really need to do things the right way, before they are sent off. No one really checks that here.

Do you feel that you are able to meet the demands put on you? 
Yes, so far so good (laughing), it has not been that bad. It is going just fine.

Of course this kind of relationship is not the result of complete freedom and trusting responsibility from a goodnatured, insightful and humane manager. You may also look at it as being a sign of organisational- or managerial values being inscribed in the bodies and minds of the employees. In some sense, it could be seen as a sign of total control. Regardless of perspective, you find that this type of organising is appreciated by the employees to a high extent - it is a form of regenerative work.

\section{The care unit}

In the case of the assistant nurses, their positive experiences were primarily concerned with increased learning through their work. The overall picture of their work situation and of specific patients was vastly increased and more complete than prior to any changes. They were included in contexts that they were previously excluded from. "For instance we participate in the sitting rounds, my voice is just as important in this context, offering a sense of belonging, which feels nice ...," says an assistant nurse. Furthermore, the new organising of work helped answer questions that were previously never asked or even identified. Apart from learning, the assistant nurses talked about a change in status. Respect and understanding of their professional roles increased as well as their status.

The work of the assistant nurses seems to them and their environment to have become more significant, noticed and better regarded. From a performance perspective, the stories of the assistant nurses dealing less with their performances "becoming better," and this is actually not in focus at all in their narrations. Alternatively they say that they are now able to understand their roles in the greater context, simply saying that they are now able to understand what they do and why they did not like it before. The things they do are, generally speaking, the same as before, the how of it, however, has changed and has helped increase their sense of contribution in the social context.

This is not true if we look at the medical nurses. Although this group also pointed to the same changes and improvements, they identified slightly different effects in terms of their performance. The narrations of the medical nurses deal with how they interpret their assignment and the prerequisites offered to them that enable them to perform better at work. They said that their assignment ought to focus on the patient, not simply on the diagnosis but on the human being. The previous organisation did not quite concur with how the medical nurses looked at their assignment. Thus, the narrations of the medical nurses have more to do with their experiences of feeling inadequate before and now having a sense of doing good enough. Perhaps even feeling that they had done a great job.

Because when you got home you
thought about everything. Did I do
this and did I do that? I did not! ...
and you picked up the phone and
called someone at work ... of
course you still call them but not
nearly as often. Sometimes you
would wake up in the middle of
the night ... and realising that
I forgot about that and you just
had to go down to the kitchen. 
Otherwise you were unable to go back to sleep. That is not true anymore, it is much quieter. I think it feels much nicer. (Medical nurse at the Delta Department)

An important point raised in all of the various professional groups was that today they feel as if they are able to finish working with a patient. You were allowed to really finish. They also talk about shifts in the rooms, from a care office to more down-to-earth modules, and that you paid more attention to the patient earlier on: "... you hear patients that are worried, and it is easier to interrupt what you are doing and go check on them. If I had been posted at the far end of the corridor, I would never have heard them."

\section{DISCUSSION AND CONCLUSION}

With the intent of looking at sustainable prerequisites for the well-being and growth of individuals, we have conducted an explorative study of two organisations. Our objective was to shift focus from compensative approaches to the work environment into looking at the potential of a work place in order to increase the level of people's energy. Hence, our question is: which everyday work processes may contribute to sustainable prerequisites for the subjective well-being and growth development of individuals?

Thus, regenerative work has been in focus of this study. Hence, we take a step forward in terms of understanding the contributing factors to the growth development and subjective well-being of individuals through their work and organisation. How are we to understand everyday processes in an organisation that are important to regenerative work?

The result of this study identifies three central themes that are important to regenerative work, seen from the perspective of sustainable prerequisites (Ericsson, 2010). The first theme deals with a general overview and participation. Results on a general level show that overview and participation are clear markers of sustainable prerequisites. Two different occurrences were connected to this particular theme. At the manufacturing company, it was directly linked to the managerial group, and at the care unit this theme had to do with a new work model, PFC.

Narrations from the manufacturing company mainly deal with participation in the managerial group and thus participation, which generate a sense of general overview in co-workers. The equivalent theme was found at the care unit in terms of their new division of work load. The medical nurses shift focus from administration to patient care. This change in organisation also meant that the assistant nurses and the medical nurses were now able to work in a team. Such changes will, of course, affect their general experience of working (Weick, 1995).

The modern view on patient care means that you look at the whole patient, while previous focus was purely on the diagnosis. Such an extended view on people requires that various functions are allowed to overlap at times. The introduction of PFC created good prerequisites for integration and exchange of knowledge, prerequisites that benefited and lived up to the wish for general overview and participation. 
A general overview for those working at the care unit has to do with the patient, and an integration of two fields of expertise, that is, care and medical issues. Through an integration of these fields, the knowledge of the individual increases. However, at the manufacturing company, the general overview deals with insight and practical- and actual ability to join in and influence decisions that concern the entire company.

Dialogue is a prerequisite for the general overview and participation at both the manufacturing company and the care unit. Without dialogue none of this would be realised. Consequently, dialogue is a tool used to construct a process of participation and a tool for making sense of the individual parts of the whole and how these are connected. You cannot distinguish between these three concepts, that is, general overview, participation, and dialogue. In this context, they correlate and actually exist because of the others. This collaboration offers prerequisites for our final theme: performance.

Two aspects on the concept of performance emerge through the study of our material. They deal with re-evaluating personal performance and how one feels that changes in performance could improve quality. They employees at the manufacturing company and the assistant nurses do not particularly change in terms of what they do at work. Their work pretty much remains the same throughout their stories. The organising of the work, however, primarily in terms of understanding work assignments and the design of the actual work changes visibly. The manufacturing workers and the assistant nurses say that they have gained new understanding of their work assignments, of their own importance and professional roles. They emphasise the fact that they "discover" their personal contribution to a social context. The other aspect on performance we found in medical nurses. Their stories revolve around the interpretation of their assignment. They focus on the patients, and that is their main assignment. The interpretation of their assignment is the same as it was prior to the implementation of PFC. Changes in work methods enabled the medical nurses to spend more time and effort on actually performing the tasks that they wanted to. They described performance, and these descriptions mainly dealt with doing a good job and being able to finish things properly.

Regenerative work concerns the invested resources of a person (emotional and cognitive) that are refuelled through the work process, perhaps even further developed. Mari Kira (2003) says that regenerative work is perceived as being understandable, manageable, and meaningful. As stated by Antonovsky (1987) and Kira (2003) our study identifies these processes and prerequisites that are mentioned above by Kira. Our material forms a complement as it focuses on a sequence of actions and events that form the basis for experiences of one's work. By interpreting the material through the theoretical lens of Kira, we may conclude that general overview and participation, dialogue and performance are significant processes and prerequisites for enabling understandable, manageable, and meaningful work, that is, regenerative work. 


\section{REFERENCES}

Aldwin, C.M. (1994). Stress, coping, and development. An integrative perspective. New York, NY: Guilford.

Alvesson, M., \& Kärreman, D. (2011). Qualitative research and theory development: Mystery as method. Thousand Oaks, CA: SAGE.

Antonovsky, A. (1987). Unraveling the mystery of health: How people manage stress and stay well. San Francisco, CA: Jossey-Bass.

Backström, T., van Eijnatten, F.M., \& Kira, M. (2002). A complexity perspective. In P. Docherty, J. Forslin, \& A.B. Shani (Eds.), Creating sustainable work systems - Emerging perspective and practice (pp. 65-75). London: Routledge.

Bosma, H.A., Kunnen, S.E., Van der Meulen, M., \& Van Halen, C.P.M. (2001). A selforganizational approach to identity and emotions: An overview and implications. In H.A. Bosma, \& S. Kunnen (Eds.), Identity and emotion. Development through self- organization (pp. 202-230). Cambridge, MA: University Press organizational.

Braverman, H. (1974). Labor and monopoly capital: The degradation of work in the twentieth century. New York, NY: Monthly review.

Brulin, G., \& Ekstedt, E. (2003). Ett hållbart arbetsliv kräver legitimitet - dags för ett nytt arbetsorganisatoriskt kontrakt [A sustainable working life requires legitimacy - time for a new contract in work organization]. In C. Von Otter (Ed.), Ute och inne $i$ svenskt arbetsliv [Outside and inside in Swedish working life] (pp. 377-393). Stockholm: Arbetslivsinstitutet.

Coffey, A., \& Atkinson, P. (1996). Making sense of qualitative data. Complementary research strategies. Thousand Oaks, CA: SAGE.

Czarniawska, B. (1999). Det var en gång en stad på vatten - Berättelser om organisering och organisering av berättelser [Once upon a time there was a city on water - stories on the organization and the organization of stories]. Stockholm: SNS Förlag.

Czarniawska, B. (2008). Narratives in social science research. London: SAGE.
Docherty, P., Forslin, J., \& Shani, A.B. (Eds.). (2002). Creating sustainable work systems: Emerging perspectives and practices. London: Routledge.

Ericsson, U. (2010). Om organisering av det regenerativa arbetet. Samtal om roll, process och interaktivt meningsskapande [On organising of the regenerative work]. (Dissertation 2010:04, Industrial Economics and Management Royal Institute of Technology, KTH, Stockholm).

Eriksson, N. (1991). Arbetskrav, egenkontroll och socialt stöd - komponenter i den psykosociala arbetsmiljön [Demand at work, self-regulation and social support - components of the psycho-social working environment]. In B. Furåker (Ed.), Arbetets villkor [Working conditions] (pp. 151-174). Lund: Studentlitteratur.

Foldspang, L., Mark, M., Mørk Puggaard, K., Melchior Poulsen, O.M., Johansson, U., Ahonen, G., \& Aasnaess, S. (2011). Measuring work well-being in Nordic countries. Copenhagen: Tema Nord 2011: 569.

Forslin, J. (Ed.). (2003). Regenerativt arbete. In Friskfaktorer $i$ arbetet [Regenerative work. In Health factors at work]. Stockholm: Prevent.

Frankenhaeuser, M. (1995). Kvinnligt, Manligt, Stressigt [Female, Male, Stressful]. Höganäs: Bra Böcker.

Furåker, B. (Ed.). (1991). Arbetets villkor [The conditions of work]. Lund: Studentlitteratur.

Gardell, B. (1976). Arbetsinnehåll och Livskvalitet. En sammanställning och diskussion av samhällsvetenskaplig forskning rörande människan och arbetet [Job content and quality of life. A summary and discussion of social science research on human beings and work]. Stockholm: Prisma.

Hackman, R., \& Oldham, G.R. (1975). Development of the job diagnostic survey. fournal of Applied Psychology, 60(2), 159-170.

Hansen, L.H., \& Orban, P. (Eds.). (2002). Arbetslivet [The working life]. Lund: Studentlitteratur.

Holmqvist, M. (2006). Medikalisering av arbetslöshet [The medicalization of unemployment]. In M. Holmqvist (Ed.), Hälsans styrning av arbetet [Controlling 
work through health] (pp. 27-60). Lund: Studentlitteratur.

Jahoda, M. (1979). The impact of unemployment in the 1939s and the 1970s. Bulletin of the British Psychological Society, 32, 309-314.

Johansson, A. (2005). Narrativ teori och metod: med livsberättelsen i fokus [Narrative theory and method: On life stories]. Lund: Studentlitteratur.

Johansson, B.K., \& Johansson, J. (2004). Framtidens arbetsmiliö - och tillsynsarbete [Work environment of the future - and supervision]. Lund: Studentlitteratur.

Kahn, R.L. (1981). Work and health. New York, NY: Wiley.

Karasek, T., \& Theorell, T. (1990). Healthy work. Stress, productivity, and the reconstruction of working life. New York, NY: Basic Books.

Kira, M. (2003). From good work to sustainable development. Human resources consumption and regeneration in the postbureaucratic working life (Dissertation, 2003:3, Industrial Economics and Management Royal Institute of Technology, Stockholm).

Kira, M., \& Forslin, J. (2008). Seeking regenerative work in the post-bureaucratic transition. Fournal of Organizational Change Management, 21(1), 76-91.

Lennerlöf, L. (1999). Arbetsledning $i$ förändring. Ett socialpsykologiskt perspektiv [Management of change. A social psychological perspective]. Stockholm: Publica/Liber.

Monat, A., \& Lazarus, R.S. (Eds.). (1991). Stress and coping. An anthology. New York, NY: Columbia University Press.
Palm, K. (2008). Det riskabla Engagemanget. Om regenerativ utveckling av mänskliga resurser, eldsjälar och ledarskap $i$ radikal utveckling [The dangerous commitment. About regeneration and development of human resources, champions and leadership during radical change] (Dissertation, 2008:04, Industrial Economics and Management Royal Institute of Technology, KTH, Stockholm).

Pettersson, P. (1994). Förändringsstress vid teknisk och organisatorisk omvandling: en studie av arbetsledare inom verkstadsindustrin [Change and stress at technological and organizational transformation: a study of supervisors in the engineering industry] (Dissertation, Stockholms universitet, Stockholm).

Stacey, R.D. (2001). Complex responsive processes in organizations. Learning and knowledge creation. London: Routledge.

Theorell, T. (2003). Är ökat inflytande på arbetsplatsen bra för folkhälsan? [Is increased influence in the workplace good for public health?]. Östersund: Statens Folkhälsoinstitut.

Von Otter, C. (2003). Ute och inne i svenskt arbetsliv [Outside and inside in Swedish working life]. Stockholm: Arbetslivsinstitutet.

Weick, K.E. (1979). The Social Psychology of Organizing (2nd ed.). New York, NY: McGraw-Hill.

Weick, K.E. (1995). Sensemaking in Organizations. London: SAGE. 